Tarih Kültür ve Sanat Araştırmaları Dergisi

Revue des Recherches en Histoire Culture et Art مجلة البحوث التاريخية والثقافية و الفنية
Vol. 7, No. 4, November 2018

Copyright (C) Karabuk University http://kutaksam.karabuk.edu.tr

\title{
DOI: 10.7596/taksad.v7i4.1838
}

Citation: Khuzina, E., \& Mukhtarova, R. (2018). The Lexico-Semantic Analysis of the Common and Various in World of Gender Picture in the English and Tatar Linguistic Cultures. Journal of History Culture and Art Research, 7(4), 214-222. doi:http://dx.doi.org/10.7596/taksad.v7i4.1838

\section{The Lexico-Semantic Analysis of the Common and Various in World of Gender Picture in the English and Tatar Linguistic Cultures}

\author{
Ekaterina Khuzina ${ }^{1}$, Rezeda Mukhtarova ${ }^{2}$
}

\begin{abstract}
Phraseological unit is a peculiar unit of language, as complex and contradictory as language and culture. The results of a contrastive description of phraseological units cast light on the general and the differing of conceptual metaphors, which predetermines the similarities and differences of linguistic world-images. The ways of reflecting the extralinguistic reality being different for each individual language are formed in linguistic world-images. As a result, each language view of the world is characterized by cultural concepts, attitudes, and stereotypes. The value world view is a part of the linguistic world-image, since the reasoning about the good and the evil is an integral part of any society, language and culture. The universal concepts such as person, man, woman are reflected in language, and every culture comprehends its own values that must be inherent in person, man, woman. What determines these values - what is good and what is bad? An obligatory component of evaluation which directs the movement of the value judgment along the estimation scale is value stereotypes and attitudes. Linguistics demonstrates how social stereotypes influence the perception of the words such as "woman", "man". Social stereotypes often provoke discussions and turn into acute problems with the democratization of society, for example, a good wife - the keeper of the hearth, the hostess in the house. This paper, by comparing Tatar and English languages, examines gender structure in phraseological units.
\end{abstract}

Keywords: Phraseological unit, Gender picture of the world, Metonymic model of a phraseological unit, the mechanism of transfer, Substantive component.

\footnotetext{
${ }^{1} \mathrm{PhD}$, associate professor, Kazan Federal University - Naberezhnye Chelny Institute, Department of Philology. E-mail: EkAHuzina@kpfu.ru

$2 \mathrm{PhD}$ in Philology, associate professor, Naberezhnye Chelny Pedagogical Institute. E-mail: rezedamuh@gmail.com
} 


\section{Introduction}

The study of phraseology in terms of defining gender stereotypes is very fruitful. The selected vocabulary, of course, does not provide exhaustive information about the gender picture of the world of English and Tatar language cultures, but we can take the print of the similar and the differing in the gender metaphors of the bearers of these cultures of language.

Gender stereotypes define the social attitude to a person depending on one's gender. Phraseological units $(\mathrm{PhU})$ with a substantive component that expresses the category of gender have an anthropological focus, regardless of whether a component of PhU is a person or an animal. As is known, zoonyms have a huge value potential and are often used in phraseology to characterize a person. Their application to human being is aimed at comparing with the animal and attributing certain positive or negative qualities.

\section{Methods}

The authors of the article use semantic and statistical analysis, comparison and generalization.

\section{Results and Discussions}

In both languages, there is a tendency towards the use of PhU woman's themes to characterize both genders, usually to show a mean spirit of a person. This is non-characteristic for PhU of man's themes that also often have a negative connotation. But the asymmetry is evident.

Comparing the $\mathrm{PhU}$ with a component denoting a person, in English the component designating feminine gender 'girl' brings a negative seme in PhU girl boy - "effeminate boy". So in PhU old wife - "rumor monger", old woman - "timid, fussy man", to play the woman - "to be frightened, to behave like man does not do". Gossip, cowardice, weakness are the indicators of nonnormality of behavior for man. The phraseological units mother's boy - "маменькин сынок" / "mother's darling", to be tied to one's mother's apron strings - "цепляться за мамину юбку"; in the Tatar language the PhU анасы яламаган малай “неопрятный, грязный мальчик"/ "slovenly, dirty boy", 'ана итәгенә ябышып йөру - "цепляться за мамину юбку" / "the boy who hangs on to his mother's apron strings" are negatively connoted. Affection towards the mother characterize the man as weak, i.e. unworthy approval.

In English the words 'woman', 'wife', 'girl', 'quee' in the phraseological units drag queen - "homosexual", old wife - "gossip", "scandal monger", old woman - "timid, fussy man", you big girl's blouse - "coward" are applied to describe a man as one with the qualities characteristic of a woman, a man who is unagreeable for society. The words 'man', 'boy', ' $g u y^{\prime}$, 'king', for comparison, are not used to characterize a woman. As applied to a man, the PhU with these components have a positive, neutral or balanced evaluation:

To be a man - "быть мужчиной";

A good boy - "паинька";

The king of the streets - "король улиц".

In Tatar the use of the words 'кыз', 'жиңги', 'маржа' 'хатын', 'кодача' in relation to a man also describe him negatively:

Итәксез хатыннар - "weak man", "fancy pants"

Туйдан качкан кыз - "a person, who disappears at the crucial moment";

Пудыр жиңги - "a man who uses make-up"; 
Сакаллы маржа - "а squealer";

Кондырлы кодача - "а capricious person".

Coquetry, non-compulsion, inability to hold one's tongue are considered to be exclusively feminine qualities. If a man behaves like a woman, he is ridiculed by society.

Unlike English, in the Tatar language, the component 'up' (male) is rare, but it is used to characterize a woman:

Ирдавай хатын - “a manlike woman".

A woman with masculine qualities does not correspond to the standard notion of femininity, and, accordingly, is not approved by society.

When studying gender stereotypes, it should be noted that the $\mathrm{PhU}$, characterizing a person, are divided into thematic groups: 1) appearance, physical qualities; 2) character; 3) intellectual and other abilities; 4) marriage, marital status, relations between a man and a woman; 5) moral qualities; 6) social status, occupation; 7) the general characteristic.

Comparing man's and woman's stereotypes in different thematic groups in English and Tatar, in the English language the most part of the PhU in the thematic group "appearance, physical qualities" are referred to woman. The PhU with positive connotation describe her as being attractive, sexy:

A sweater girl - "a full breasted girl";

A pin-up girl - "cover girl, beautiful";

A glamour girl - "beauty";

The belle of the ball - "the reigning beauty, the rose of the ball".

The PhU of this group, characterizing a woman, a girl in Tatar are few. This is due to the fact that only her husband or an immediate relative, as well as a man engaged to this girl are qualified to assess the looks of a girl, a woman, especially her sexual attractiveness. In Tatar the PhU of positive evaluation that describe the appearance of a girl usually have the meaning of 'a girl the best there is':

Ипи-тоз матур кыз - "а beautiful girl".

The PhU with negative evaluation describe a woman as being unattractive:

In English:

A slip of a girl - "a skinny girl".

In Tatar:

Aт күк кыз - "а muscular girl”

In English the PhU, describing the man's appearance in most cases stress his strong body, power:

As strong as an ox (bull) - “здоров как бык";

As hearty as a buck - "крепкий как олень".

The PhU describing the man's appearance are few in English, since beauty is not a necessary quality for a man in English:

A Teddy boy - "stylish";

A slip of a boy - "thin, thin reed". 
In the Tatar language a man should be good-looking:

Чибар егет - "a handsome boy".

However he should not dress up, brag about his handsomeness, since to smarten oneself up is not characteristic for a man:

Tәmu ezem - "a dandy".

Кәлтафри егет - "a dandy, a smartened up".

The thematic group "intellectual and other abilities" notes the intellectual incompetence of women. The PhU woman's reason in English and хатын-кыз логикасы - "woman's reason" in the Tatar language reflects the public opinion about the female intellect as illogical. In the PhU in English mother wit "common sense" - the component 'mother' is an intensifier but does not apply to women in general.

The $\mathrm{PhU}$ of this group, relating to men, has a ring of the $\mathrm{PhU}$ of the thematic group "public status, occupation". In English there is a great variety of areas of men: they can be poets and military, they can almost everything:

$$
\begin{aligned}
& \text { A son of Muses - "a poet"; } \\
& \text { A son of Mars - "military"; }
\end{aligned}
$$

A man of all work - "a person who does every job about the house".

The thematic group "marriage, marital status, relations between a man and a woman" occupies a special place in phraseology, especially in Tatar. As is known, family is a unit of society, and man and woman are its two components.

The importance of being married for a woman is stressed in the Tatar language:

$$
\begin{aligned}
& \text { Ирле хатын - "a married woman". } \\
& \text { Кияугә чыгу - "to get married". } \\
& \text { Unmarried women are disapproved: } \\
& \text { Карт кыз - "old maid"; } \\
& \text { Утырган кыз - "to remain unmarried too long"; } \\
& \text { Ирсез-кушсыз яшәү - "to live alone". }
\end{aligned}
$$

In Tatar there are practically no such PhU about a man. The PhU mол әтәч - "a man - a widower who does not grief for his wife's death but rides the high horse" brings out negative emotions.

In English the man's unwillingness to get married is considered to be usual:

$$
\text { A confirmed bachelor - "закоренелый холостяк". }
$$

A bachelor girl in the English language does not invoke such negative associations as in Tatar (a bachelor girl - "одинокая девушка"), but nobody wants to remain unmarried (an old maid - “старая дева").

Extramarital relationships are vividly reflected in phraseology of both languages.

In English:

The other woman - "a lover";

A fancy girl - "a lover". 
In Tatar:

Ир өстенндн йөру — "to be unfaithful to one's husband".

Such PhU have negative connotation in both languages.

In English and in Tatar married women whose husbands practically do not live at home, preferring other occupations excite pity and irony:

In English:

A golf/football widow - "a woman whose husband plays golf/football".

A grass widow - "a woman whose husband is away".

In Tatar:

Ирле тол - "a wife without a husband".

In both languages, the supremacy of a woman over a man is considered unacceptable, unworthy of a man:

In English:

Grey mare - "the wife who loves to rule".

In Tatar:

Хатыны баш - "his wife wears the trousers";

Хатын адъютанты - "а man who is under the thumbs of his wife".

Of particular interest are, in our opinion, the PhU related to the thematic group "moral qualities". The phraseological units reflecting immoral behavior refer mainly to women.

In English:

A woman of the street - "a prostitute";

A lady of easy virtue - "a loose woman";

As an actress said to the bishop - "one says when it is related to sex". In Tatar:

Урам хатыны - "а prostitute";

Кызың жилен жибаргән - "your daughter is pregnant";

Ир тастымалы - "freebee".

A woman has always been found sinful. The PhU with the meaning "lover" are single, but they are absent in the Tatar language.

It is noted in the thematic group "social status, occupation" that a woman's place is in the house, she is a mistress and a jack-of-all-trades there:

In English:

A woman's touch - "женская рука";

The lady of the house - "mistress of the house". 
In Tatar:

Кыз башыннан йөргән эш - "a woman's work".

In English the PhU of the thematic group relating male are characterized by great diversity:

Knight of the pen - "a writer";

The big boy - "personage", "boss";

The backroom boys - "men who are on undercover duty".

In Tatar phraseology has a folk origin and is limited to village themes, so the PhU with the male component of this group are few:

$$
\text { Агай-эне - авыл-күрше - "country-man". }
$$

In the thematic group "general characteristic" the PhU with positive connotation are mainly referred to man:

In English:

$$
\begin{aligned}
& \text { A broth of a boy - "fine fellow"; } \\
& \text { Boy wonder - "child prodigy". }
\end{aligned}
$$

In Tatar:

Eгет солтаны - "the ideal of a man".

Thus, the stereotypes with a predominance of negative evaluativity in "female" phraseology are universal for English and Tatar. A woman draws praise and positive emotions if she is beautiful and if she is devout. In the Tatar language, a married woman, the mistress of the house are approved. There is practically no other occupation for a woman in the Tatar society. In English the woman has lager selection in the professional field, the scope of her activity is wider than in the Tatar language. In both languages, women's intellectual abilities and their morality are poorly assessed. The morality of men is almost never mentioned. Men have an abundance of various negative character traits, which are mainly associated with undue familiarity, a love for drinking, a quick temper and a weakness for the female sex. However, these negative qualities do not evoke such negative emotions as women. The male "negative" is normal. A man, in the absence of female qualities in him and weakness for the female sex and amusements, is recognized as the standard of all that is positive in man.

Although the holiness of the concepts such as "mother" is recognized, a woman as an abstract concept is associated with weakness, untrustworthiness, cowardice and a source of trouble

What, then, determines the commonality of stereotypes in English and Tatar phraseology?

Of course, not only mythology and religion affect the perception of men and women. It is important to take into account the national and cultural, historical features of the people - the native speaker of a language. It is necessary to take into account the role of the intermediary language - the Russian language, which is a source of information of other languages being in contact with it and, accordingly, the cultures.

It is interesting that the idea of a man is reduced to one image - strong, intelligent, aggressive, whereas the idea of a woman diverges at two poles: positive and negative. On the one hand - the holy virtue, mother, sister, on the other hand - a fallen woman, a prostitute. Such model is universal for most cultures, as shown by gender studies. 


\section{Summary}

Both images are reflected in the phraseology of both languages. So, PhU have a positive connotation if the basis of the $\mathrm{PhU}$ is the image of mother, sister, or caring woman. The PhU with a female component, characterizing a woman or a man, in most cases has a negative meaning.

In the phraseology of English and Tatar, two diametrically opposite images of a woman stand out.

I. A woman - mother (sister), holy, innocent:

In the English language:

Mother Superior - "prioress".

In the Tatar language:

Мәрьям ана - "The Virgin Mary".

II. A dragon lady, a toxic woman, a prostitute:

In the English language:

A girl about the town - "a loose woman";

There is a woman in it - "look for the woman".

In the Tatar language:

Урам хатыны - "a prostitute".

Let us compare with the image of a man:

I. A man possessing diverse qualities - positive and negative (an ordinary man):

In the English language:

A man of the world - "whale of a fellow";

A tough guy - "macho".

In the Tatar language:

әтәч Гали - "a man with fiery temper";

Егет дисәң дә егет - "a nice guy".

II. An effeminate, unexperienced, weak man:

In the English language:

Mother's boy - "an effeminate man".

In the Tatar language:

Базар маржасы кебек - "like a noisy woman”.

\section{Conclusions}

Thus, the image of a man does not have such a variety of representations as the image of a woman. If the characteristics of a man go beyond the gentleman's behavior, then it is no longer a man. One cannot say the same about a woman. 
The conducted investigation enables to assert that both linguistic cultures have androcentricity, the Tatar language to a greater degree (this can be observed by the example of the uneven distribution of PhU among the thematic groups in accordance with gender stereotypes). In English and Tatar, with a significant difference in cultures, there is a great commonality - "female" component in the PhU in most cases has a negative emotional evaluation marking. The exception is the $\mathrm{PhU}$, which is based on the image of mother, sister, a respectable wife (such PhU are few). As analysis shows, English and Tatar are characterized by a large isomorphism of value representations. The differences in the distribution among the groups are explained by the national specifics of the phraseology of the English language and the Tatar language.

A man is associated with strength, courage, persistence, although he has a number of negative traits, for example, quick temper, swagger, propensity for leading a wild life and women, and other traits. A man with female qualities (weakness, talkativeness, etc.) is not approved by society. A woman in most cases is a source of all troubles - a chatty, immoral, dangerous person. In rare cases, a woman calls forth admiration - a mother, a decent wife, a loving sister. Of particular high value is a married woman, a mother in the Tatar language.

Interesting is the fact that the PhU of woman's themes are used to characterize both genders, usually bad qualities. The PhU of man's themes characterize mainly men and, in comparison with "woman's" PhU do not evoke so negative emotions as contempt (Уйнашчы хатын - "a street girl", Mother's boy "goodie").

An attempt to explain the negative emotional-value marking of PhU with the female component led to the following conclusion. At all times a woman was treated in two ways - she was praised (Virgin Mary) and considered to be dangerous (Eve). A woman is a paradoxical being. She attracts and she is toxic. The analysis of mythology, religion and culture leads us to the conclusion that a negative attitude towards a woman has arisen from the subconscious fear of the woman's natural power, her unpredictability.

\section{Acknowledgements}

The work is performed according to the Russian Government Program of Competitive Growth of Kazan Federal University.

\section{References}

Ibragimova, I. I. (1993). Contrastive Analysis of Somatic Phraseological Units (based on the materials of English and Tatar): Dissertation for Candidate of Philological Sciences. Kazan.

Kirilina, A. V. (2002). The Problems of Gender Approach to the Study of Cross-Cultural Communication. Gender as an Intrigue of Cognition. Moscow: The MSLU Press.

Molotkov, A. I. (1977). Basics of Phraseology of the Russian Language. L.: Nauka.

Moon, R. (1994). The Analysis of Fixed Expressions in Text. In M. Coulthard (eds.), Advances in written text analysis, (pp.117-135). London: Routledge.

Moon, R. (1998). Frequencies and Forms of Phrasal Lexemes in English. In A.P. Cowie (eds.), Phraseology: Theory, analysis, and applications, (pp.79-100). Oxford: Oxford University Press.

Rosemarie, G. (1998). The Stylistic Potential of Phraseological Units in the Light of Genre Analysis. In A.P. Cowie (eds.), Phraseology: Theory, analysis, and applications, (pp.125-144). Oxford: Oxford University 
Press.

Smith, W. G. (1970). The Oxford Dictionary of English Proverbs Text. Oxford: Oxford University Press.

The International Dictionary of English language Text (1997). Cambridge: Cambridge University Press.

The New Encyclopedia of Britannica Text (1994). London: Encyclopedia Britannica, Inc.

Vagabov, M. V. (2003). Woman in Islam. Moscow: Umma.

Vasyuk, V. V. (2002). Concept "Woman" in Statics and Dynamics of English Phraseology: Dissertation for Candidate of Philological Sciences. 